\title{
Exploring the Training Mode of Innovation and Entrepreneurship Talents for Logistics Engineering in the Field of Postal Express Delivery
}

\author{
-Taking Logistics Engineering of BIGC as an Example
}

\author{
Yuan Zhang \\ School of Mechanical and Electrical Engineering \\ Beijing Institute of Graphic Communication \\ Beijing, China
}

Lei Zhu

School of Mechanical and Electrical Engineering Beijing Institute of Graphic Communication

Beijing, China

\author{
Zhenqing Gao* \\ School of Mechanical and Electrical Engineering \\ Beijing Institute of Graphic Communication \\ Beijing, China \\ Yanping Du \\ School of Mechanical and Electrical Engineering \\ Beijing Institute of Graphic Communication \\ Beijing, China
}

\author{
Xiaojing Yang \\ School of Mechanical and Electrical Engineering \\ Beijing Institute of Graphic Communication \\ Beijing, China
}

\begin{abstract}
With the sustainable prosperity of E-commerce Industry, the postal express has become the fastest-growing area in the logistics industry in China, but it also faces a serious shortage of high-level specialized personnel. In order to better adapt to the current development of the postal express industry and the needs of enterprise talents, the authors discusses some problems in the reform of innovative entrepreneurship training mode of logistics engineering specialty, and takes the school where the authors are working as an example to make a beneficial attempt. Firstly, the study outlined the logistics engineering, especially the demand and training of senior professionals in the field of postal express in China, and then analysed four new trends of the new era, new subjects, new goals and new challenges faced by the current cultivation of doublecreative talents in logistics engineering specialty, finally summarized the exploratory work done by the specialty in training high-end and compound talents in the field of postal express from four aspects: course system construction, undergraduate scientific research training, subject competition organization and participation, and social service.
\end{abstract}

Keywords-Logistics engineering; Postal express; Innovative and entrepreneurial talents; Training mode

\section{INTRODUCTION}

In recent years, the leaders of the state have attached great importance to the innovation and entrepreneurship education in colleges and universities. Premier Li Keqiang once instructed that "College students are the fresh force in implementing innovation-driven development strategy and promoting mass

The Teaching Reform Project of BIGC (No. 22150119002/010). entrepreneurship and innovation. They should not only study earnestly and grasp more knowledge, but also devote themselves to innovation and entrepreneurship and improve their practical ability". It can be seen that deepening the reform of innovation and entrepreneurship education in colleges and universities plays an important role in promoting the implementation of innovation-driven development strategy. Innovation and entrepreneurship education is the key content of China's higher education reform. Promoting the reform of innovation and entrepreneurship education in institutions of higher learning is not only the fundamental need to serve the transformation of economic structure and development momentum in the new period of our country, but also the inevitable need to train applied and innovative talents [1]. Therefore, innovative entrepreneurship education needs to be integrated into the talent training system, reform the teaching content and methods, improve the curriculum and strengthen practice.

In the environment of mass entrepreneurship and innovation, China's logistics industry also shows a vigorous momentum of development. From 2010 to 2017, the total amount of social logistics in China climbed from 125.4 trillion yuan to 252.8 trillion yuan, with a compound annual growth rate of $10.53 \%$. The proportion of total logistics expenditure to GDP decreased from $17.8 \%$ to $14.6 \%$ [2]. In recent years, express logistics has been the fastest developing industry in the property industry, whose scale and efficiency are constantly improving. In 2018, the National Express business volume exceeded 50 billion pieces, and the output value exceeded 
trillion yuan. With the rapid growth of express logistics industry, technological and innovation have become an effective way to reduce costs and increase efficiency, and gradually show the irreplaceable importance. At the same time, there are many opportunities and flexible capital in the field of e-commerce and express logistics, which have also become fertile ground for young people to start their own businesses. However, in the process of transforming express logistics from labor-intensive to technology-intensive, the shortage of engineering technology and high-end $R \& D$ related talents is becoming more and more obvious, especially the serious lack of high-level composite application talents.

Since 2015, universities in the postal and telecommunications industry, such as Beijing University of Posts and Telecommunications, Xi'an University of Posts \& Telecommunications and Chongqing University of Posts and Telecommunications, have offered undergraduate majors related to postal express, but most of them have not graduated yet. At present, more than 100 colleges and universities in China have set up logistics management or logistics engineering related majors. Although colleges and universities are gradually involved in the forefront of postal express development in the reform of the subject system, most colleges and universities still need to improve in training students' innovation and entrepreneurship ability.

At present, there are still some deficiencies in the training of innovative talents in logistics engineering in colleges and universities in terms of professional characteristics and orientation, practical ability, teaching methods and so on[3]. The characteristics and orientation of logistics engineering majors in most domestic universities are relatively vague, and there is a lack of systematic analysis of the knowledge structure, skills and corresponding qualities needed by logistics enterprises, which leads to the lack of pertinence in the curriculum design of logistics engineering majors. In addition, the teaching method and process of emphasizing the imparting of professional knowledge and neglecting the cultivation of practical ability and innovative ability still lack. There are still some deficiencies in the training of innovative thinking ability and practical ability.

Therefore, according to the characteristics of higher education and the demand for double-creative talents in the development of logistics industry, how to effectively implement double-creative education for professional talents and reform the training mode of logistics engineering professionals are of great significance to improve the quality of logistics professionals and to promote the rapid and healthy development of postal express industry. [4].

Beijing Institute Of Graphic Communication, where the authors is studying, is the first institution of higher learning to directly train undergraduate talents in the field of postal and express delivery, except for colleges and universities of posts and telecommunications. With the major of logistics engineering as the main support, it has been approved as a national training base for postal talents. In recent years, logistics engineering specialty has continuously refined its characteristics and direction of cohesion, and has carried out exploratory research on the cultivation of innovative talents based on scientific research and training.

\section{THE "Four-NEW" TREND OF LOGISTICS ENGINEERING PROFESSIONAL TALENTS TRAINING}

Under the background of the rapid development in the field of postal express and the reform of higher education in China, the exploration and reform of the training mode of innovative and entrepreneurial talents for logistics engineering specialty need to keep up with the industry trends and technological frontiers. Therefore, it is necessary to clarify the current situation and trend of the times, industries, science and technology, policies and other aspects, so as to carry out education and teaching reform.

\section{A. New Age}

As a typical comprehensive and cross-cutting engineering specialty, logistics engineering specialty should provide talent foundation and intellectual support for the implementation of the five development concepts of innovation, coordination, green, open and sharing and the spirit of the CCP Nineteenth National Congress. Therefore, we should keep pace with the development of the times and the current situation of ideological and political education in higher education in formulating the direction and goal of personnel training. At the same time, it should be highly suited to the major strategic development needs such as "The Belt and Road", "Yangtze River Economic Belt" and "Beijing-Tianjin-Hebei Integration".

\section{B. New Engineering}

In order to actively explore a new training mode that conforms to the law of engineering education and the characteristics of the times, the concept of "New Engineering" was put forward in 2017. Since then, "Fudan Consensus", "Tianjin University Action" and "Beijing Guide" and a series of "Combination Boxing" have been launched one after another[5]. For logistics engineering specialty, "new subject" education is to focus on the trend of market development and strive to create new outstanding engineers to meet the needs of society and enterprises.

\section{New Goals}

In view of the higher requirements of logistics industry and logistics professionals in the new era and new engineering, the training of logistics engineering professionals must achieve higher goals. It includes not only the renewal of theoretical knowledge (such as artificial intelligence, robotics, internet of things, intelligent hardware, etc.), but also the improvement of practical innovation ability and the cultivation of entrepreneurial management ability [6]. In other words, the training objectives of logistics engineering innovative and entrepreneurial talents need to truly reflect the training characteristics of high-end compound talents.

\section{New Challenges}

Faced with higher requirements and goals, we are also facing unprecedented new challenges in the process of achieving and cultivating goals. For example, how to integrate ideological and political education into professional teaching, how to implement the educational concept of new engineering, realize seamless connection between schools and enterprises, 
how to deal with and guide the post-00 students, and how to properly utilize the intelligent teaching environment and means in the era of "Internet plus"[7]. These are all deeply studied and solved in the cultivation of logistics engineering talents.

\section{Characteristic of Double Creative TAlentS TRAINING IN LOGISTICS ENGINEERING SPECIALTY OF BEIJING INSTITUTE OF GRAPHIC COMMUNICATION}

Faced with the above "Four New" situation, Beijing Institute of Graphic Communication keeps pace with the changing situation in the training of creative talents. College office of academic affairs has formulated a number of incentives for the cultivation of innovative and entrepreneurial talents, supported a number of projects of college students' innovative and entrepreneurial plans, held a number of innovation and entrepreneurship exchanges, and achieved certain results in the cultivation of innovative and entrepreneurial talents. On this basis, the major of logistics engineering has also been put into practice in curriculum system, scientific research and training, subject competition, training certification and so on.

\section{A. Course System Construction for Postal Express}

With the traditional advantages of school publishing media and printing packaging, the logistics engineering specialty of Beijing Institute of Graphic Communication highlights its characteristics in curriculum system setting. It is obviously different from most domestic universities which offer logistics engineering specialty. Especially in the direction of "Ecommerce logistics", aiming at the serious shortage of high-end management and technical personnel in the field of express mail service, we have carried out targeted training of high-end compound talents.

In terms of curriculum system construction, the authors' major has formulated a "3.5 + 0.5" high-end engineering talent training program. In the first semester to the seventh semester, school learning is the main method, and in the eighth semester, fixed-position internship is the main method. In terms of curriculum design, courses with characteristics of "Introduction to E-commerce Logistics", "Logistics Packaging Technology", "Frontier Technology and Equipment of Express Logistics", "Modern Postal Regulations and Standards" have been offered, so that students can fully understand the frontiers of science and technology development and the application of new technologies in the field of E-commerce Logistics and Postal Express. On the basis of theory teaching, practical courses such as "Comprehensive Cognitive Practice of Postal Enterprises" and "Comprehensive Course Design of Postal Enterprises" have been set up.

\section{B. Systematic undergraduate scientific research training}

In order to improve students' ability of scientific research and innovation, the Work Program of Scientific Research Training Program for Logistics Engineering Undergraduates and the Regulations on Management of Scientific Research Assistants for Logistics Engineering Undergraduates of Beijing Institute Of Graphic Communication have been specially formulated, and the scientific research training program for undergraduates has been systematically implemented. Starting from the second grade, the two-way selection of students and instructors is carried out, and the instructors guide students to participate in the actual research projects.

In addition, the authors' logistics engineering specialty also puts forward a systematic "seven-step method" of scientific research innovation training for undergraduates, which covers the whole process of scientific research work. Its specific working process is shown in Fig. 1. As of July 2019, 53 people have participated in the actual scientific research projects, including 7 patent applications for invention, 2 academic papers and 2 project research reports completed by undergraduates.

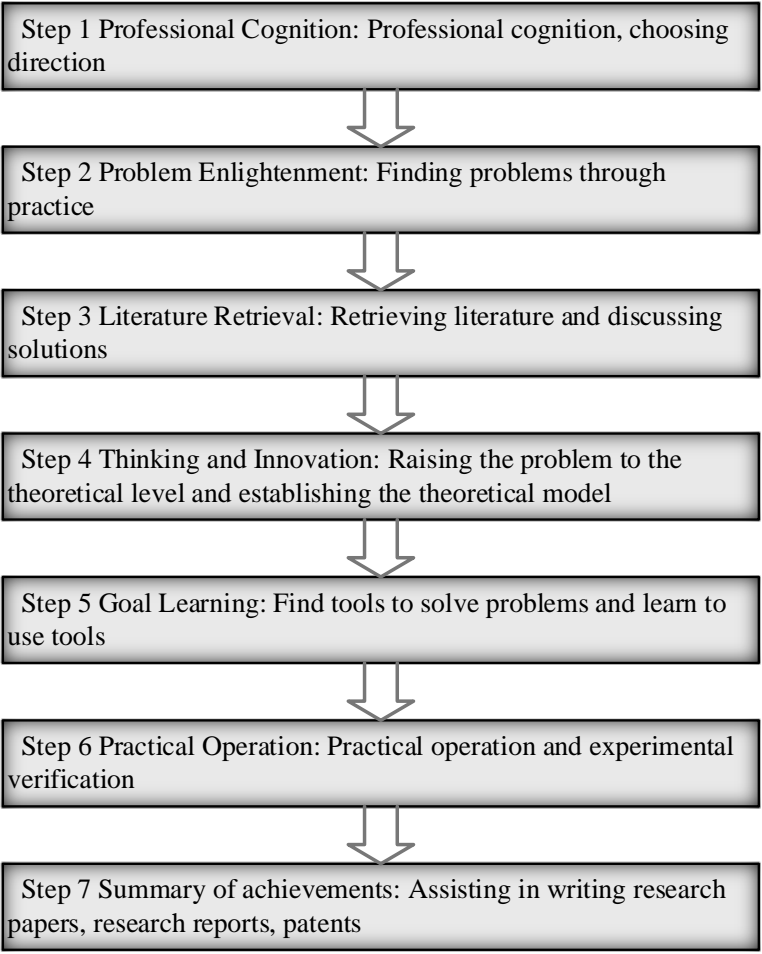

Fig.1. The scientific research training seven-step workflow

\section{Step1: Professional Cognition, Choosing Direction}

Through the first semester of the "Introduction to Logistics Engineering" course, we arrange at least three presentations by well-known experts outside the school, so that students have a basic understanding of the field of logistics engineering, and guide students to pay attention to the direction they are interested in.

\section{Step2: Finding problems through practice}

It is mainly through the first semester of the practical course "Logistics Engineering Comprehensive Cognitive Education" to lead students to visit the field, the instructor targeted to guide students to find practical engineering problems. At the same time, it also helps students to choose a problem that students are interested in as well as the content of the actual project in the light of the scientific research projects undertaken by the teachers. 


\section{Step 3: Retrieving literature and discussing solutions}

To guide students to understand the work foundation of their predecessors, to teach them how to retrieve and read various documents, to make basic innovations, to set up discussion groups to discuss with students, and to guide students to put forward feasible solutions.

Step 4: Raise the problem to a theoretical level and build a theoretical model

Improve students' understanding of theoretical models and help students' complete practical engineering problems to establish theoretical models. At the same time, the process from practical problems to theoretical models is clarified by combining the professional courses such as Logistics and Operational Research with the undergraduate mathematical modeling contest organized by the school's basic department.

Step 5: Find tools to solve problems and learn to use them

Instruct students to solve problems according to different theoretical models, find appropriate tools, and guide students to self-study the use of tools.

\section{Step 6: Practical operation and experimental verification}

Lead students to the actual site of engineering problems, guide students to carry out practical operations, formulate experimental programs, and complete the verification of theoretical models.

Step 7: Assist in writing research papers, research reports, patents and summarizing results

Gradually guide students to start writing research papers, let students participate in the writing of some chapters of research reports, guide students to summarize their innovative ideas into intellectual property rights.

\section{Organize students to participate in multi-type and multi- field Subject Competitions extensively}

In the past 3 years, the logistics engineering specialty of authors' university has actively carried out undergraduate research and training work to further cultivate students' practical innovation ability, closely linked to the National Contest On Logistics Design by University Students (NCOLD), the National Internet + Express College Students' Innovation and Entrepreneurship Competition, the E-commerce logistics Packaging Design Competition, China College Students' Entrepreneurship Competition, the North China University Robot Competition, the National University Student Mechanical Innovation Design Competition and other highlevel discipline competitions, innovative entrepreneurship training.

Firstly, the authors' major divides the competitions into five categories: logistics planning, logistics equipment, logistics information, logistics packaging and comprehensive design. Based on the research projects and directions of competition instructors in the field of logistics, special reports and seminars are organized within the professional scope to cultivate student groups. Secondly, combining with the seven-step method mentioned above, and registering for the subject competition based on the content of scientific research projects actually participated in, students can be more familiar with the process of scientific research and share basic research tasks while cultivating their modeling, optimization, writing, practical ideas and abilities. Furthermore, through the discipline competition, students can be organized to carry out combat drills, achieve the purpose of comprehensive training, improve the innovation level of students' team, and encourage students to further stimulate their innovative practical ideas and consolidate students' innovative practical results.

In addition, in order to encourage students to participate in subject competitions, the specialty also incorporates the performance of Subject Competitions into the performance evaluation of professional courses, which helps to apply classroom theoretical knowledge to practical projects and deepens students' understanding and mastery of classroom theoretical knowledge.

\section{Encourage students to participate in professional-related social services}

In recent years, the authors' major in logistics engineering has actively participated in and sponsored various activities under the guidance or sponsorship of People's Republic of China State Post Bureau and Beijing Post Administration. In these activities, teachers actively guided students to participate in service work. In the China Express Last Kilometer Summit for three consecutive years from 2016 to 2018, students of this major participated in the statistics and data analysis of express green packaging volume. In the First Green Express Entry into Campus Activities, students of this major actively participated in the design and production of exhibition boards, and actively publicize express green packaging to the public during the activities. In the First Course on Green Development of Express Industry, the students of this major participated in the training activities together and participated in the whole process of conference services. In the 1st Beijing post industry vocational competition, the students of this major undertook the work of invigilator assistant for theoretical examination and referee assistant for practical examination.

In these logistics-related social service activities, students can better understand the development status of the industry, deepen their understanding of the industry and enterprises, and then clear learning objectives and employment orientation.

\section{SUMMARY}

Based on the analysis of the current situation of personnel training in the field of postal express, which has developed rapidly in recent years, this paper analyses the "Four New" situation faced by the cultivation of innovative and entrepreneurial talents in Logistics Engineering specialty. Taking the logistics engineering specialty of Beijing Institute of Graphic Communication as an example, this paper expounds the beneficial exploration of the specialty in training high-end compound innovative and entrepreneurial talents in the field of postal express from four aspects: curriculum system, scientific research and training, subject competition and social service.

\section{ACKNOWLEDGMENT}

The author(s) disclosed receipt of the following financial support for the research, authorship, and/or publication of this 
article: This work is supported the Teaching Reform Project of BIGC (No. 22150119002/010).

\section{REFERENCES}

[1] Jun Guo, Yinhuan Yang, "Double Creation" Accounting Personnel Training Mode Innovation Research Based on Core Competence under the Background of Internet, The Guide of Science \& Education, China Academic Journal (CD-ROM Edition) Electronic Magazine Co., Ltd. China, pp. 63-64, 2017. (In Chinese)

[2] Jianfa Wang, Development ideas and strategies of modern logistics industry based on the perspective of reducing cost and increasing efficiency, Practice in Foreign Economic Relations and Trade, China Association of International Trade. China, pp. 89-92, 2019. (In Chinese)

[3] Dezhi Zhang, The Reform and Practice on the Training Mode of Logistics Engineering Talents based on Innovation Ability Development, Logistics Engineering and Management, China Academic Journal (CD-
ROM Edition) Electronic Magazine Co., Ltd. China, pp. 154-156, 2018. (In Chinese)

[4] Yang Li, Lihua An, Shengling Xiao, et al, Practical Research on Training Innovative and Entrepreneurial Talents in Logistics Engineering Major-Taking Logistics Engineering Major of Northeast Forestry University as an Example, Inheritance and Innovation -Improving the Quality of Higher Education, 2014. (In Chinese)

[5] Aihua Wu, Yongfeng Hou, Qiubo Yang, et al, Accelerating Development and Construction of Emerging Engineering, Taking Initiative to Adapt to and Lead the New Economy, Research in Higher Education of Engineering. China, pp. 7-15, 2017. (In Chinese)

[6] Liguo Z, Performance evaluation system of logistics engineering practical teaching course in application oriented undergraduate based on rough set theory, IEEE International Conference on Grey Systems \& Intelligent Services. China, 2015.

[7] Fu H, Integration of Logistics Simulation Technology and Logistics Learning Factory in a Two-stage Teaching Method for Logistics Management Courses, International Journal of Emerging Technologies in Learning (IJET). China, pp. 62, 2017. 